\title{
The Role of Nepalese Political Parties in Democracy (1990-2018)
}

By Thapaliya, Ram Sharan

Mr. Thapaliya is Pursuing PhD from Tribhuvan University, Contact: email:

\begin{abstract}
This research paper analyzes the role of political parties in the democratic period of 1990-2018. This period was dominantly ruled by Nepali Congress and Nepal Communist Party (NCP)United Marxist Leninist (UML). This paper explores how the major political parties revisited their political policies and diversified their scope after the second people's movement (SPM) as a way to address the pressure exerted by the inclusion agenda forwarded by the then Nepal Communist Party-Maoist. After the king assumed direct executive power through a political coup, the coalition of the parliamentarian parties knows as Seven Party Alliance and the rebelling Maoist party reached a twelve-point understanding which consequently led to declare Nepal a democratic republic with a parliamentary system of governance. But the intraparty feuds and the ideological divides between the democratic and the communist parties remain.
\end{abstract}

Keywords: Political Parties, Democracy,

\section{Introduction}

This research paper discusses the role of political parties in institutionalizing democracy in Nepal after the restoration of democracy in 1990 till 2018. Kelly and Ashiagbor have considered "political parties form a cornerstone of democratic society". The authors further view that "they aggregate the interests of the public, articulate them in the form of policy options and provide structures for political participation. In addition, they train political leaders and contest elections to seek a measure of control over government institutions" (Kelly and Ashiagbor, 2011). It means that political parties are a heart-soul chamber of democracy. They always clearly set up their principles, programs, and ideology to be open and democratic. Political parties play a significant role in the state democratization process, political transformation, and reflection of political dynamism. Therefore, political parties and democracy are considered as the two sides of the same coin. In this regards, Khanal views, "Political parties are the inseparable elements of representative democracy" (2001, p.11). It shows that political parties are power-point of the state and a provide lifeline to keep democratic norms and values intact. All the democratic 
government are party governments, and political parties help to keep government democratic (ibid, p.12). The role of political parties in the democratic process has been important, and in some respects indispensable, but the role is not always virtuous and positive (Bickerton, 2010, p.3).

\section{Methods and Objectives}

The study is completely based on the review of literature of Nepalese political movement and democracy. The study explores the roles of political parties since 1990 to 2018 in the democratic movements of Nepal. The study also analyses the pros and cons of then governments and Maoists' movements.

\section{Discussions}

\section{Origin and development of Political Parties in Nepal}

Political parties are the most vital component of the political system. Political parties in Nepal have evolved through different phases of its almost seventy-year long history that have changed the political course, and in turn, their own organizational outlook. The years between 1930 and 1960 could be considered as the formative phase of political parties in Nepal (Hachhethu, 2002, p.1). Nepali political parties were rather suddenly created by the educated middle class as an instrument for bringing in democracy (ibid). There were very few political parties in existence during the first decade of political party's history. Prachanda Gorkha is the first party formed in Nepal. The Prachanda Gorkha was organized in 1927 under the leadership of Chandan Singh. It is already defunct now. It was not a political party but a clique of people who had taken to sporadic terrorist activities. Nepal Praja Parishad, established in 1936 AD (1993 BS), was the first party to at public attraction of problems of democracy in Nepal (The Economic Weekly, 1952).

\section{Nepali Congress}

The Nepali Congress is evergreen and more influential political party in Nepali history. "Nepali Congress is a lumbering umbrella-type party. Its long records of suffering and struggle against oppressive regimes have earned it a national and international reputation of being a mass-based, liberal-democratic organization" (Gupta, 1994). The Nepali Congress is the first party to struggled against the Rana regime and demanded democracy. Moreover, "the Nepali Congress party was formed with the sole purpose of getting the country rid of Rana autocracy and establishing in the country a political system that was based on the parliamentary system of government" (Dhungel, 2007, p.29). 
At the initial phase, Praja Parishad leaders have started a democratic movement in 1940. Firstly, the Nepali Congress formed ad hoc committee Akhil Bhartiya Rashtriya Nepali Congress under the chairman of Devi Prasad Devkota and general secretary Krishan Prasad Bhattarai. The leaders are like Tanka Prasad Acharya, B.P. Koirala, Bal Chandra Sharma, Dilli Raman Regmi, Krishna Prasad Bhattarai, Surya Prasad Upadhyaya, Ganesh Man Singh, Subarna Sumsher Rana, and others leaders profoundly united to form Nepali Congress. Besides this, the oldest party Nepali Congress birth was in exile part of Calcutta, India. The split NC formed on the merges of two Congress Party- Nepal Democratic Congress - August 4, 1948, and another is Nepali National Congress - January 25, 1947” (Nepali Congress official webpage, January 20, 2019). Officially Nepali Congress was founded on April 9, 1950 in Calcutta" (Gupta, 1993, p.165).

After the process of integration, "the NRC (Nepali Rashtriya Congress) first president was Tanka Prasad Acharya while Acharya sent in the jail sentence during the Rana regime B.P. Koirala become an acting president of NRC, while in another phase of NPC (Nepal Prajantraika Congress) the first convention appointed Mahendra Bikram Shah as its president” (Wagle, 2019). For instance, the first Nepali Congress Party was presidency by Matrika Prasad Koirala and Party Secretary headed by the Mahendra Bikram Shah. While, the both parties have four-four members nominated in the party structure. "The Nepali National Congress nominated the B.P Koirala, Ganeshman Singh, Krishna Prasad Bhattarai, and Daya Shankar Munsi and Nepal Democratic Congress appointed Subarna Sumsher, Surya Prasad Upadhyaya, Mahabir Sumsher, and Kunwar Kulu Singh" (Basnet, January 26, 2018). In the source of Rising Nepal added, "The year Chaitra 27, 2006 B.S NC came into existence, which is a historical landmark in Nepalese politics and democratic movement" (ibid). It means that the researcher analyzed NC is the first party to deliberate their socialization and political idea and agenda to the Nepali people.

Its ideology is "socialism and social democracy. It is also affiliated to socialist international" (Acharya, 2013). However, the grand old party adopted a new dynamic in the party dimension. Longtime NC had accepted multiparty democracy and Constitutional monarchy in the past but after $11^{\text {th }}$ General Convention it decided to maintain neutrality about the monarchy. The $12^{\text {th }}$ general convention had adopted federal republic substituting monarchy" (Goutm, 2019). The estimated data of the NC, the party had 316,000 active members in 2010" (The Kathmandu Post, 2015). Likewise, the Nepali Congress has always been at the forefront of democratic movements in Nepal. The party successfully led the democratic uprising of 1950, 1990, and 2006" (Shah, 2019). After the 1990 movement, the oldest party also suffered from the split and internal rift politics. The leaders like Girija Prasad Koirala and Sher Bahadur Deuba leadership strife suffered the party and its achievement. However, on 25 September 2007, Nepali Congress (Democratic) 
and Nepali Congress merged and again reunited Nepali Congress.

It is one of the oldest political parties of Nepal which played a significant role in the establishment of the liberal multi-party political system. It was the lead actor in the pro-democracy movement of 1950s and 1990s and also the principle member of the interim government in 1990-1991. Nepali Congress got the highest seats in the parliamentary elections in many cases except in 1994, 2008 and 2017. Nepali Congress was the largest party in the parliament in 1991. Nepali Congress had the opportunity to lead the government twelve times since 1990. Nepali Congress currently is the main opposition party in the parliament after the 2018 general election. After boycotting the general elections of 1981 and 1986, Nepali Congress party had participated in the 1987 local election (Whelpton, 1993, p.51).

"Both during the pre-1960 period of parliamentary politics and since April 1990, elite groups in rural Nepal naturally gravitated towards Congress as the best way of maintaining their local influence. Besides these its structural weakness: an abundance of members and aspirant member's eager for a share of the spoils, but not enough dedicated cadres willing to shoulder the day-today burden of political work. In the run-up to the election, one Congress leader put it candidly: 'the leaders and workers of Nepali Congress are in general slow, lazy and inactive" (ibid, p.53). After the death of the iconic and charismatic leader of Nepali Congress B. P. Koirala in 1982, the party was handled by the triumvirate leaders of Nepali Congress, Ganesh Man Singh, acting president Krishna Prasad Bhattarai, and party general secretary Girija Prasad Koirala. This era of the triumvirate leader was marked by intra-party feuds and betrayals within the party. In the current scenario, Nepali Congress still is faced with similar intra party feuds between two major leaders Sher Bahadur Deuba and Ram Chandra Poudel factions. As a result, Nepali Congress was downsized to very limited seats in the first parliamentary election after the declaration of the federal republic.

\section{Nepal Communist Party}

In 1930, Nepal has sweeping its revolutionary forces and their activities against feudalism and Rana regime. Mostly after the Second World War strife between two ideological thought via socialist and democratic influence Nepali political party. Likewise, the independent movement of India has an impact on the flourished communist movement in Nepal. "Communism as an organized movement in Nepal was strongly influenced by the independence movement in India and the success of the Chinese Communist revolution of 1949" (Khadka, 1995, p.56).

Notably, "the communist movement in Nepal can be broadly considered under two heads: first, 
the spread of Marxist ideas in Nepal: and second, the formation of the Communist Party of Nepal (CPN) itself in the year 1949" (Gurung, 1977). The formation of Nepal Communist Party also in exile in Calcutta, India in 1949 and its main struggled to replace the Rana regime.

The Nepal Communist Party officially founded on April 22, 1949 (Baishak 10, 2006 BS) and leader Pushpa Lal Shrestha was prominent of the NCP. The co-founder of the NCP is also Narayan Bilash Joshi, Niranjan Govinda Vaidhya, Nara Bahadur Karmacharya, and Moti Devi Shrestha" (http://cpnuml.org/content/prologue.html). While, some leaders said that the CPN was formed on the occasion of Lenin's birth anniversary on April 22, 1949" (Rawal, 2007, p.20).

Leader Pushpa Lal Shrestha is the first general secretary of the Nepal Communist Party. There are some spilled and power reshuffled entered in the CPN party. However, "effectively the party had divided into two factions; one led by the leader Tulsi Lal Amatya and other leader as Keshar Jung Rayamjhi". The party leaders were also split into two ideological approaches. In the period 1962, the Nepal Communist Party mostly divided into the Pro Chinese and Pro Soviet (Russian) blocks. The group led by K J. Rayamajhi, the main leader of the pro-Soviet Group and other leaders are Mr. B.B. Manandhar (NCP-Democratic) and Krishna Raj Burma (NCP-Burma), while in the Chinese block leaders also split into numerous faction" (Khadka,1995, p.59). The Chinese splits leaders are Tulsi Lal Amayta, Pushpa Lal Shrestha (NCP-PL). The NCP split affects the party mechanism rapidly. The leader Pushpa Lal led NCP-PL further separated into moderate left, radical left, and extreme radical left. The researcher added that the Puspha led moderate, while the radical by the Rohit, and extreme led by two group Liberation Front-1972 and People's Revolutionary Organization of Nepal-1976" (ibid, p.59). Besides this split and merger process of the Nepal Communist Party, the membership of the party is increased. In the various estimates indicate that the general membership of the various Communist parties increased from 5,000 in the 1950 s to 10,000 in the 1980 s. After the democratic change in 1990, communism gained considerable strength as its membership went up to 35,000 in 1992" (Khadka, p.57).

The leftist politics played an important role in all revolutionary in the Nepali political development. "The CPN in the 1950s, the CPN (Fourth Convention) in the 1970s and 1980s, the CPN (Unity Centre) in the 1990s and even the CPN (Maoist) advocated an alternative curse, demanding the election of the CA" (Hachhethu, 2009, p.44). In the period 1970s, the CPN (Fourth Convention) split into CPN (Masal, Mohan Bikram group), CPN (Mashal, Mohan Vaidya group), and CPN (Unity Centre). The CPN (Unity Centre)" (ibid, p.44).

Likewise, the Hachhethu added the CPN (UML) originated as a Naxalite group in the early 
1970s, committed to Mao's NPD ideology and adopted a new ideological programme called Janatako Bahudaliya Janbad (People's Multiparty Democracy, or PMD) in 1993" (ibid, p.45). Similarly, on January 6, 1991, the merger of two parties CPN (Marxist) and CPN (ML) united to form the CPN (UML). The fifth convention of the CPN (UML) led by the Man Mohan Adhikari.

After 2006 political transformation and first time held a federal election in 2018, again two communist parties closer to the merger process. The two erstwhile communist parties CPNUML and CPN-Maoist Center have merged on May 17, 2018, to form the NCP" (The Himalayan Times, 2019). Likewise, Chairman of Communist Party of Nepal (United Marxist Leninist) (CPN-UML) K.P. Sharma Oli (R) and Chairman of Communist Party of Nepal (Maoist Centre) Pushpa Kamal Dahal wave give the new powerful communist party in Nepali political development" (Xinhua, 2018).

Similarly, in the last 30 years, Nepal has become a political laboratory for many political experiments. Each experiment has failed to provide the real basic needs and peoples are still fighting for the basic needs of humanity (Joshi, 2017). The year 1990 marks a major departure in Nepal's political course. Nepal adopted a multiparty model of democracy and setting up democratic institutions. Two major political parties- Nepali Congress and the CPN-UML-along with other fringe parties like Rashtriya Prajatantra Party (RPP), Nepal Sadhbhavna Party (NSP), the Nepal Workers and Peasants Party (NeWPP). Nepal Communist Party (Maoist) initiated an armed insurgency in 1996 and joined the political mainstream after a political deal with the Seven Party Alliance (SPA). New regional identity based parties like Madhesi Jana Adhikar Forum, Nepal (MJAF-N) also came into existence.

It is the largest and dominant Communist party of Nepal. In 12018, the party merged with another important communist fringe CPN (Maoist) thus forming a new integrated party called Nepal Communist Party (CPN). The CPN (UML) was created in 1991 through the unification of the Communist Party of Nepal (Marxists) and Communist Party of Nepal -Marxists-Leninist (https://www.peaceinsight.org/conflicts/nepal/conflict-profile/key-people and-parties/). CPNUML adopted the European model of socialist democracy. The Communist Party of Nepal was formally organized by Pushpa Lal Shrestha in 1951. "The party established by Pushpa Lal Shrestha in 2006 BS was named Nepal Communist Party. Later on the party splintered to various other factions adding suffix such as Marxist Leninist, Masal, Mashal, Unified Marxist Leninist, and Maoist Centre among others" (The Kathmandu Post, February 9, 2018). The CPN-UML led the minority government of Nepal for the first time in 1994 under the leadership of moderate leader Man Mohan Adhikari. "It would be the first time Communists have taken power in any 
Asian nation after winning a multi-party election" (Burns, November 24, 1994). In this part the Communist party's leaders played a prominent role in the government until 1990, when the King held effective power and political parties were banned from contesting elections" (ibid). The unification of CPN (Marxist) and CPN-ML, which had played an important and leading role during the historic mass movement for the restoration of democracy in 1990, created a positive impact on the Nepalese society

\section{Unified Communist Party of Nepal (Maoist)}

The UCPN (Maoist) party merged with the CPN-UML in 2018 to become an integrated party called Communist Party of Nepal (CPN). It had emerged as the mainstream political party after signing the twelve-point understanding with the Seven Party Alliance (SPA). It also joined the interim government in 2008 led by Girija Prasad Koirala. UCPN (Maoist) for the first time participated in 2008 constituent assembly (CA) election and became the largest party in terms in parliamentarians in the constituent assembly. After the constituent assembly election, two leaders Pushpa Kamal Dahal 'Prachanda' and Baburam Bhattarai led the government. But it also suffered the split in the party after Mohan Vaidhya (Kiran) formed a different faction of the Maoist party called CPN (Revolutionary Maoist). Later, another influential leader Baburam Bhattarai splinted to form a new party called Naya Shakti Party. In the subsequent years, it went suffered multiple splits, as leaders kept on leaving the mother party, accusing it of "deviating from the ideology" (The Kathmandu Post, 2016).

\section{Rastirya Prajantantra Party (RPP)}

Rastriya Prajatantra Party was formed on 29 May 1990 by a group of leaders of the Panchayat system seeking a political space in the post democratic era after 1990s. This party advocated the active role of the monarch as its political manifesto. But RPP's birth in national politics was marked by controversy as the former panchas failed to unite under single leadership (Thapa, 2017). This party splintered into two factions in 1991 where the two factions were led Surya Bahadur Thapa and Lokendra Bahadur Chand. After a merger, it again splintered form the second time in 1997 (ibid). Now, there are two RPP splinters: one led by Kamal Thapa and another by Pashupati Shamsher Junga Bahadur Rana.

\section{Nepal Sadhbhavana Party (NSP)}

After the restoration of democracy in 1990, the Madhes based leader Gajendra Narayan Singh founded Nepal Sadhbhavan Party (NSP). This party participated in all the elections of Nepal. 
The party founded by Singh has been splintered into numerous parties under the leadership of Rajendra Mahato, Anil Jha, Sarita Giri, Bikash Tiwari and Shyam Sundar Gupta (The Kathmandu Post, March 2, 2015). Currently, Sadhvawana Party has merged to make a coalition of Madhesh based parties and formed a new integrated party called Rastriya Janata Party (RJP)- Nepal. Similarly, Upendra Yadav led Madhesi Janadhikar Forum has merged with other parties including Naya Shakti Party to form an integrated party called Sanghiya Samajbadi Party Nepal (Federal Socalist Forum Nepal-FSFN)

Table 1.1 Seats won by the Political parties in elections from 1991 to 1999.

\begin{tabular}{|l|l|l|l|l|l|}
\hline \multicolumn{7}{|l|}{ Election of the House of Representatives 1991-1999 } \\
\hline Election Year & $\mathbf{1 9 9 1}$ & & $\mathbf{1 9 9 4}$ & & $\mathbf{1 9 9 9}$ \\
\hline Total seats & 205 & & 205 & & 205 \\
\hline NC & 110 & NC & 83 & NC & 111 \\
\hline UML & 69 & UML & 88 & UML & 71 \\
\hline ML & 0 & NDP or RPP & 20 & RPP(Thapa) & 11 \\
\hline RPP(Thapa) & 1 & NeWPP & 4 & NSP & 5 \\
\hline RPP(Chand) & 3 & NSP & 3 & RJM & 5 \\
\hline NSP & 6 & Independents & 7 & UPF & 1 \\
\hline NPF & 0 & & & Ne WPP & 1 \\
\hline NeWPP & 2 & & & & \\
\hline UPF & 9 & & & & \\
\hline CPN(Democratic) & 2 & & & & \\
\hline Independents & 3 & & & & \\
\hline Other parties & 0 & & & & \\
\hline
\end{tabular}

$M L=$ Communist Party of Nepal (Marxists-Leninist), NSP = Nepal Sadbhavana Party, NPF = National People's Front, NeWPP = Nepal Workers and Peasant Party, UPF $=$ United People's Front, $C P N=$ Communist Party of Nepal, RJM = Rastriya Jana Morcha . 
Source: IPU \& EC (1991, 1994, and 1999).

After the elections (1991, 1994 and 1999), Nepalese political parties have exercised different forms of governments: majority government, coalition government and minority government. The armed insurgency started by CPN (Maoist) in 1996 which continued for more than a decade brought the nation to a new level of political crisis. Maoist revolution directly promoted the inclusive agenda which later resulted in the establishment of regional parties. Even though Nepali Congress received a comfortable majority in the 1991 general election, it had to pay a heavy price due to the internal dispute. The parliament was dissolved and the 1994 mid-term election made CPN-UML the largest party but with no majority.

Table 1.2: Seats won by the political parties in the elections of 2008, 2013 and 2017

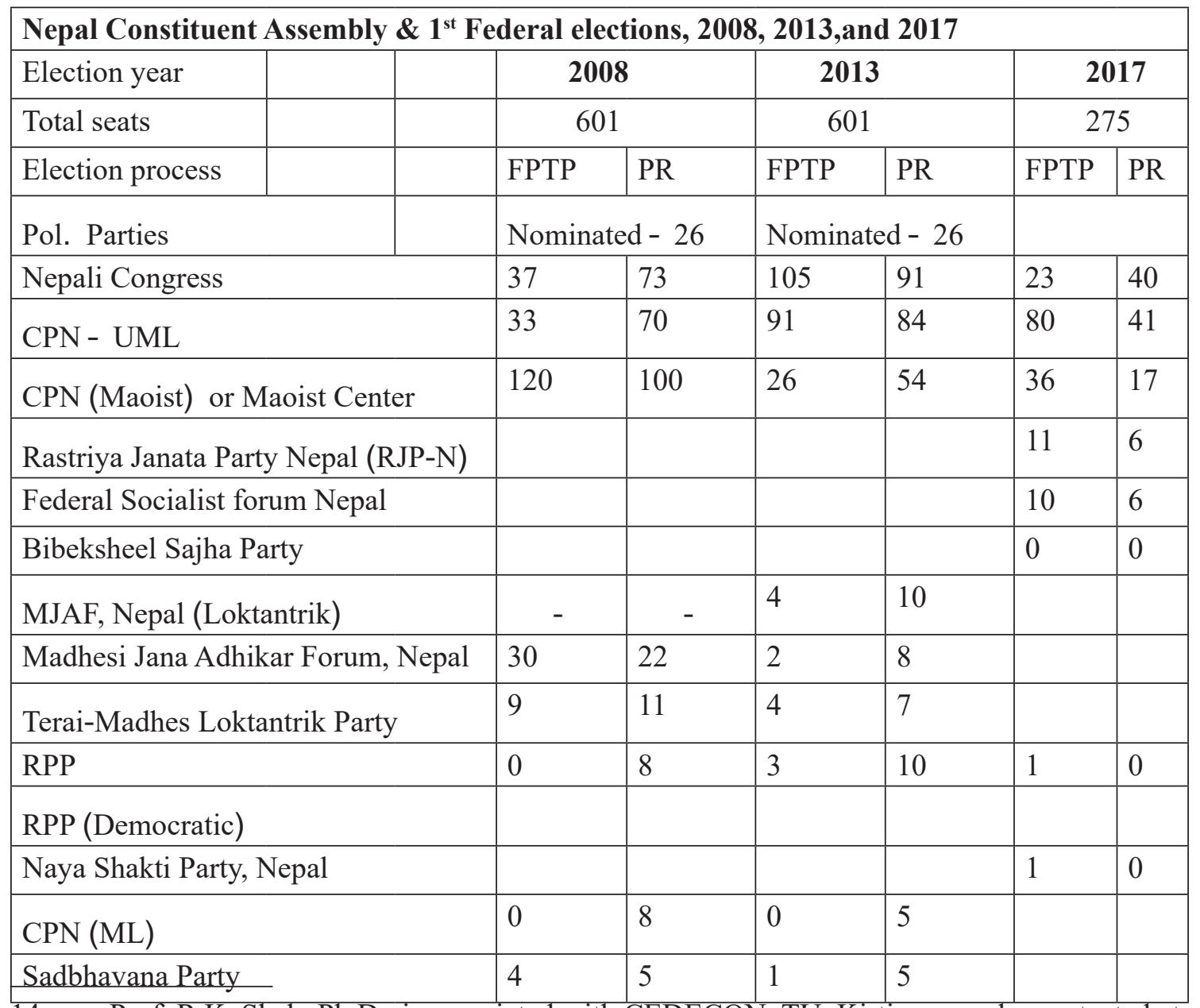

14 Prof. R.K. Shah, Ph.D., is associated with CEDECON, TU, Kirtipur, can be contacted at: drrkshah.nepal@gmail.com 
Thapaliya, Ram Sharan

\begin{tabular}{|c|c|c|c|c|c|c|}
\hline Federal Socialist Party & - & - & 0 & 5 & & \\
\hline Janamorcha Nepal & 2 & 5 & 0 & 3 & & \\
\hline CPN(United) & 0 & 5 & 0 & 3 & & \\
\hline Rastriya Madhesh Samajwadi Party & - & - & 0 & 3 & & \\
\hline RPP-Nepal & 0 & 4 & & & & \\
\hline Rastriya Janamorcha & 1 & 3 & & & 1 & 0 \\
\hline Rastriya Janshakti Party & 0 & 3 & & & & \\
\hline Nepal Workers Peasant Party & 2 & 2 & 1 & 3 & 1 & 0 \\
\hline Sanghiya loktantrik Rastriya Manch & 0 & 2 & & & & \\
\hline NSP(Anandidevi) & 0 & 2 & & & & \\
\hline Rastriya Janamukti Party & 0 & 2 & 0 & 2 & & \\
\hline Terai Madhes Sadbhavan Party & & & 1 & 2 & & \\
\hline Tharuhat Tarai Party Nepal & & & 0 & 2 & & \\
\hline Akhanda Nepal Party & & & 0 & 1 & & \\
\hline MadhesiJanadikar forum-Gantantrik & & & 0 & 1 & & \\
\hline Nepali Janata Dal & 0 & 2 & 0 & 1 & & \\
\hline Khambuwan Rashtriya Morcha Nep. & & & 0 & 1 & & \\
\hline Nepa Rashtriya Party & & & 0 & 1 & & \\
\hline Jana Jagaran Party Nepal & & & 0 & 1 & & \\
\hline Sanghiya Sadhbhawana Party & & & 0 & 1 & & \\
\hline Madesh Samata Party Nepal & & & 0 & 1 & & \\
\hline Samajwadi Janata Party & & & 0 & 1 & & \\
\hline Sanghiya L.R. Manch - Tharuhat & & & 0 & 1 & & \\
\hline CPN(Unified) & 0 & 2 & & & & \\
\hline Dalit Janajati Party & 0 & 1 & 0 & 2 & & \\
\hline Nepal Rastriya Party & 0 & 1 & & & & \\
\hline Samajbadi Prajatantrik Janata Party & 0 & 1 & & & & \\
\hline Chure Bhawar Rastriya Ekta Party & 0 & 1 & & & & \\
\hline Nepal Loktantrik Samajbadi Dal & 0 & 1 & & & & \\
\hline Nepal Parivar Dal & 0 & 1 & 0 & 2 & & \\
\hline
\end{tabular}




\begin{tabular}{|l|l|l|l|l|l|l|}
\hline Independents & 2 & & 2 & & 1 & \\
\hline
\end{tabular}

Source: Election Commission $(2008,2013,2017)$.

Tables 1.1 and 1.2 given above show the performance of the Nepalese political parties in the parliamentary elections as well as the elections of the constituent assembly and the recent election of the federal parliament. Nepali Congress got the majority in three elections in 1991, 1999 and 2013. In the recent election of the federal parliament in 2017, the coalition of two fringes of the Communist Party (CPN-UML and CPN-Maoist) got a sweeping majority with a two-third majority. The first three elections were held on the basis of first-past-the-post (FPTP) system. While in the constituent assembly election (2008 and 2013), and the 2017 general elections were conducted through a mixed electoral model of first-past-the-post and proportional representation system. In the 2017 general election, the political factions of former panchas, Rastriya Prajatanta Party, failed to secure their status as the national party. Only five political parties had secured minimum seats to be recognized as a national party.

Table 1.3. Governments in Nepal (1990-2018)

\begin{tabular}{|l|l|l|l|}
\hline Prime Minister & Participating parties & Duration & Dates \\
\hline K.P. Bhattarai & Nepali Congress + ULF Interim & 13 months & $4 / 19 / 90-5 / 25 / 91$ \\
\hline G.P.Koirala & Nepali Congress Majority & 43 months & $\begin{array}{l}5 / 26 / 91 \text { - } \\
11 / 28 / 94\end{array}$ \\
\hline M.M. Adhikari & UML minority & 9 months & $\begin{array}{l}11 / 29 / 94 \\
10 / 09 / 95\end{array}$ \\
\hline S.B. Deuba & Nepali Congress - NDP-NSP & 18 months & $9 / 11 / 95-3 / 11 / 97$ \\
\hline L.B. Chand & NDP-UML-NSP coalition & 6 months & $\begin{array}{l}03 / 12 / 1997- \\
10 / 7 / 1997\end{array}$ \\
\hline S.B. Thapa & NDP-Nepali Congress & 6 months & $\begin{array}{l}10 / 7 / 1997- \\
04 / 15 / 1998\end{array}$ \\
\hline G.P. Koirala & Nepali Congress minority & 5 months & $4 / 15 / 98-8 / 25 / 98$ \\
\hline G.P. Koirala & Nepali Congress - ML-coalition & 4 months & $\begin{array}{l}8 / 26 / 98 \\
12 / 22 / 98\end{array}$ \\
\hline
\end{tabular}




\begin{tabular}{|c|c|c|c|}
\hline G.P. Koirala & $\begin{array}{l}\text { Nepali Congress- UML-NSP } \\
\text { coalition }\end{array}$ & 5 months & $\begin{array}{l}12 / 23 / 98- \\
5 / 31 / 99\end{array}$ \\
\hline K.P. Bhattarai & Nepali Congress & 10 months & $5 / 31 / 99-3 / 22 / 00$ \\
\hline G.P. Koirala & Nepali Congress & 28 months & $3 / 22 / 00-7 / 26 / 01$ \\
\hline S.B. Deuba & Nepali Congress & 14 months & $7 / 23 / 01-10 / 4 / 02$ \\
\hline L.B. Chand & $\begin{array}{l}\text { NDP (Chand Faction) - appointed } \\
\text { by the king] }\end{array}$ & 7 months & $\begin{array}{l}10 / 11 / 02- \\
05 / 30 / 03\end{array}$ \\
\hline S.B. Thapa & $\begin{array}{l}\text { NDP (Thapa Faction) - appointed } \\
\text { by the king }\end{array}$ & 11 months & $\begin{array}{l}06 / 04 / 03- \\
05 / 07 / 04\end{array}$ \\
\hline S.B. Deuba & $\begin{array}{l}\text { - NC (Democratic)-appointed by } \\
\text { the king }\end{array}$ & 8 months & $\begin{array}{l}06 / 02 / 04- \\
02 / 01 / 05\end{array}$ \\
\hline $\begin{array}{l}\text { King Gyanendra- } \\
\text { Chairman of the } \\
\text { Cabinet }\end{array}$ & $\begin{array}{l}\text { Tulsi Giri and Kirti Nidhi Bista } \\
\text { Former Prime Ministers during } \\
\text { Panchayat era) Vice Chairmen } \\
\text { of Council of Ministers appointed } \\
\text { by King. King held the position } \\
\text { of the Head of the government as } \\
\text { the chairman of the ministerial } \\
\text { council }\end{array}$ & 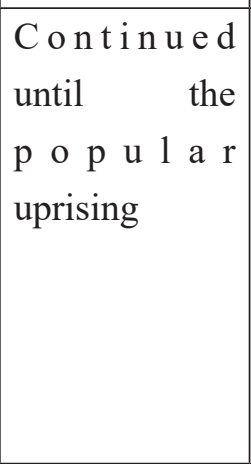 & $\begin{array}{l}02 / 14 / 05- \\
04 / 25 / 2006\end{array}$ \\
\hline G.P. Koirala & Nepali Congress & $\begin{array}{l}28 \text { months and } \\
2 \text { days }\end{array}$ & $\begin{array}{l}04 / 25 / 2006- \\
08 / 18 / 2008\end{array}$ \\
\hline P.K. Dahal & $\begin{array}{l}\text { Unified Communist Party of Nepal } \\
\text { (Maoist) }\end{array}$ & $\begin{array}{l}9 \text { months and } \\
10 \text { days }\end{array}$ & $\begin{array}{l}08 / 18 / 2008- \\
05 / 25 / 2009\end{array}$ \\
\hline M. K. Nepal & Communist Party of Nepal (UML) & $\begin{array}{l}20 \text { months and } \\
22 \text { days }\end{array}$ & $\begin{array}{l}05 / 25 / 2009- \\
02 / 06 / 2011\end{array}$ \\
\hline J.N. Khanal & Communist Party of Nepal (UML) & $\begin{array}{l}6 \text { months and } \\
24 \text { days }\end{array}$ & $\begin{array}{l}02 / 06 / 2011- \\
08 / 29 / 2011\end{array}$ \\
\hline B. Bhattarai & $\begin{array}{l}\text { Unified Communist Party of Nepal } \\
\text { (Maoist) }\end{array}$ & $\begin{array}{l}18 \text { months and } \\
23 \text { days }\end{array}$ & $\begin{array}{l}08 / 29 / 2011- \\
03 / 14 / 2013\end{array}$ \\
\hline
\end{tabular}




\begin{tabular}{|l|l|l|l|}
\hline K. R. Regmi & Independent & $\begin{array}{l}11 \text { months and } \\
4 \text { days }\end{array}$ & $\begin{array}{l}03 / 14 / 2013 \text { - } \\
02 / 11 / 2014\end{array}$ \\
\hline S. Koirala & Nepali Congress - NCP (UML) & $\begin{array}{l}20 \text { months and } \\
8 \text { days }\end{array}$ & $\begin{array}{l}02 / 11 / 2014- \\
10 / 12 / 2015\end{array}$ \\
\hline K. P. Oli & $\begin{array}{l}\text { Communist Party of Nepal } \\
\text { (UML)- UCPN (Maoist) }\end{array}$ & $\begin{array}{l}9 \text { months and } \\
27 \text { days }\end{array}$ & $\begin{array}{l}10 / 12 / 2015- \\
08 / 04 / 2016\end{array}$ \\
\hline P. K. Dahal & UCPN (Maoist) & $\begin{array}{l}10 \text { months and } \\
7 \text { days }\end{array}$ & $\begin{array}{l}08 / 04 / 2016- \\
06 / 07 / 2017\end{array}$ \\
\hline S.B. Deuba & Nepali Congress - UCPN & $\begin{array}{l}8 \text { months and } \\
13 \text { days }\end{array}$ & $\begin{array}{l}06 / 07 / 2017- \\
02 / 15 / 2018\end{array}$ \\
\hline K. P. Oli & Nepal Communist Party & --- & $\begin{array}{l}02 / 15 / 2018 \\
\text { onwards-- }\end{array}$ \\
\hline
\end{tabular}

Source: Riaz and Basu (2007), https://en.wikipedia.org/wiki/List_of_Prime_Ministers_of_Nepal

From 1990 to 2018, Nepal saw 27 different governments most of which were coalition based. The need to secure a majority in the parliament led to bribing of the parliamentarians which introduced a bad culture in Nepali politics. In such a context, parties in opposition tried to take advantage of factionalism in governing parties to pull down governments rather than keeping a check on the government's policies and performances (Thapliya, 2006, p.54). Similarly, Nepalese politics was highly affected by nepotism and corruption along with the the intra-party feuds and betrayals. Individual leaders were becoming more crucial than the party system which weakened the democratic process at large.

The post 1990 polity of Nepal witnessed leadership crisis and unstable governments. Kumar views, "Internecine intra-party factionalism and intra-party rivalry for the seat of government power have distorted the electoral process, delegitimizing the role of elected representatives and recognition of voter preference, and finally leading to a breakdown of democracy" (2008, p.2728). But the important political development in the post 1990 polity is the introduction of the agenda of identity and inclusion. It concretized with the success of the second people's movement and the promulgation of the interim constitution after overthrowing monarchy in 2007.

\section{Defining Democracy in Nepal}

Democracy in general is a governance system that upholds the principles of the rule of law, human 
rights, freedom and public accountability. The equivalent Nepali term for democracy is 'loktantra'. 'Lok' means people and 'tantra' means rule. In that sense, democracy is the rule of the people. People are the 'soul' of the political system, i.e., the 'body'. Political parties need to keep people in the centre of their policies. Democracy promotes open societies. In the word of the former president of the United States Abraham Lincoln, democracy is a form system "by the people, of the peoples and for the people". That means democracy inherently embodies the aspiration of the people. And political parties implement those aspirations through their policy and programmes. Nepali history has witnessed a long struggle for institutionalizing democratic institutions and legal frameworks.

Democracy is meaningless without party democracy (Nahar, 2017, p.79). In this context, Nepalese political parties have stood strong for the democratic model of governance system. The historical political movements have proved parties' commitment to democracy and pluralism. After the successful political transformation to democracy in the 1950, the first government was led by Mohan Sumsher under the tripartite agreement between the Ranas, the King, and Nepali Congress party. During that time, other political parties had not gained strong public recognition. It was only eight years after the regime change that political parties had the chance to participate in the parliamentary election on 18 February 1958. It is a landmark in Nepali political history where people formally elected their representatives through their votes. But in next two years, the entire process of democratization was seized through a military coup that led to the introduction of a partyless Panchayat system. Nepalese democracy was and is guided by Indian capitalism and Chinese socialism (Badal, 2019).

Nepali political parties then had to consolidate their power to overthrow the partyless 'undemocratic' system for the next thirty years until a new political deal was made between the King and the alliance of political parties (Nepali Congress and Samyukta Baam Morcha). The janaandolan (people's movement) of the 1990 restored the sovereignty of the people to be exercised by their representatives from the political parties. But the sovereignty was also shared by the monarchy.

Similarly, after the royal takeover of 2002, the rebelling CPN (Maoist) joined its effort together with the seven-party alliance of the major political parties to overthrow the monarchy in the country through a second phase of janaandolan in 2006-2007. This movement was crucial because it was able to overthrow the 238 years long old-monarchy and at the same time brought the Maoist party to the political mainstream through a Comprehensive Peace Agreement (CPA).

A survey of the political history shows that Nepali political parties have played an important role 
in establishing democratic system of governance and other institutions. After the movement of the 2006-2007, Nepal fundamentally moved forward with a new form of electoral system which practiced a mixed model of first-past-the-post and proportional representative model. The constitution of 2015 made Nepal a constitutionally secular country that adopted federal republican form of political organization.

The constitutional change introduced and practiced after the 1990 regime change is a crucial beginning towards a more liberal society which gave the marginalized groups a right to dissent even if it did not empower them in other ways. That is way Krishna Hachhethu believes that the restoration of democracy through the 1990 popular movement was a landmark event for the transformation of political parties in Nepal (p.93). The illegitimate parties gained legitimate powers as recognized by the constitution.

After the 1990 movement, forty political parties were established out of which only 23 actually participated in the general election of 1991(Khanal, 2001, p.16). Despite these exciting numbers of political parties there were serious flaws in the working of the political parties which were internally not very democratic in their organizational arrangements. In most of the major political parties, the same leader took hold of the party's leadership for a long time. Thapa (2006) views that "Nepalese parties have always been very closed and weakly organized hierarchical organizations characterized by authoritarian leadership, undemocratic structure and exclusionary approach". $\mathrm{He}$ further added, "Democracy failed in Nepal because it lacked a participant political culture. If our way of thinking does not change, even the best polity will betray us" (ibid). But Mahendra Lawoti has rightly pointed out that the open polity after 1990 facilitated the process by providing a space for mobilization. People being articulating their problems, needs, and aspiration in this open environment (Lawoti, 2007, p.34).

\section{Conclusion}

This paper concludes that Nepalese political parties played a crucial role in the established of the democratic political system by leading popular people's uprising in 1990 and 2006-2007. All the political parties have principally agreed to the democratic values that include the rule of law, human rights, freedom of expression and press freedom. They have also agreed to the democratic parliamentary system with provincial structures for a greater decentralization and autonomy. They have committed to good governance and public accountability by forming institutions and policies to secure those goals. The mainstream political parties, therefore, can be credited for the institutionalization of democracy in Nepal in the post 1990 political context. 


\section{References}

Badal, B.P. (2019). Roles of Rahul Sankrityayan in Nepalese Cultural Tourism, Research Nepal Journal of Development Studies, year 2, issue 1. Kathmandu, pp 13-21.

Bickerton, J. (2010). Parties and Democracy in Canada: Regional Fragmentation, Institutional Inertia, and Democratic Deficit. California: Prager an imprint of ABC.CLIO.LLC. pp.3-25.

Burns, J.F. (1994). Communist plan to form Government in Nepal. The New York Times, November 24. https://www.nytimes.com/1994/11/24/world/communists-plan-toform-government-in-nepal.html.Retrieved March 15, 2019.

Chengcheng. (2017). Nepal's CPN-UML emerges as largest party in historic elections. Xinhua net, December 13. http://www.xinhuanet.com/english/2017- 12/13/c_136823470. htm.Retereved March 21, 2019.

Dahal, G. (2017). Democratic Practice and Good Governance in Nepal. Journal of Political Science, Vol. XVII, pp.1-18. Retrieved March 16, 2019.

Dhungel, D.N. (2007). Inside Out political parties of Nepal. Kathmandu: Institute for Integrated Development Studies (IIDS).

Khanal, R. (2001). Democracy in Nepal - challenges and prospects. Kathmandu: Smriti books. Pp.1-110.

Gurung, M.D. (1977). Communist Movement in Nepal. Economic and Political Weekly, Vol.12, No.44, pp.1849-1852. https://www.jstor.org/stable/4366057.

Gupta, A. (1993). Politics in Nepal 1950-60. New Delhi: Kalinga Publications.

Hachhethu, K. (2002). Party Building in Nepal - organization, leadership and people: A comparative study of the Nepali Congress and the Communist Party of Nepal (Unified Marxist - Leninist). Kathmandu: Mandala Book Point.

Hachhethu, K. (2000). Nepali Politics: political parties, political crisis and problem of governance. Center for Nepal and Asian Studies (CNAS), Tribhuvan University. Pp.90-116. 
Hachhethu, K. (2009). The Communist Party of Nepal (Maoist): Transformation from an Insurgency Group to a Competitive Political Party. European Bulletin of Himalayan Research 33-34: 39-71 (2008-2009). Retrieved July 27, 2019.

Joshi, D.R. (2017). Polarized Politics, Yeah! .Spotlight magazine, November 10. Vol.11, No.08. Retrieved March 5, 2019.

Kelly,N. and Ashiagbor,S. (2011). Political Parties and Democracy in Theoretical and Practical Perspectives - Parliamentary Groups. Washington, DC: National Democratic Institute (NDI). Pp.1-63.

Khadka, N. (1995). Factionalism in the Communist Movement in Nepal. Columbia: Pacific Affairs, University of British Columbia. Vol. 68, No. 1, pp. 55-76.

Kumar, D. (2008). Obstacles to local leadership and democracy in Nepal. New Delhi: Sage Publications. Pp.25- 44.

Lawoti, M. (2007). Contentious politics and democratization in Nepal. New Delhi: Sage Publications.

Levin, M. (1992). The spectre of Democracy- the rise of modern democracy as seen by its critics. London: MacMilian Academic and Professional Ltd.

Nahar, M.Q. (2017). The role of political parties in democracy: Bangladesh perspective. Social Science Journal, No.21. Pp.77-86. Retrieved March 20, 2019.

Rawal, B. (2007). The Communist Movement in Nepal: Origin and Development. Kathmandu: Achham-Kathmandu Contact Forum.

Riaz, A \& Basu,S. (2007). The State-Society Relationship and Political Conflicts in Nepal (1768-2005). New Delhi: Journal of Asian and African studies. Vol.42 (2), pp.123142. Retrieved March 19, 2019.

Thapa, G. (2006). Democracy in Nepal: Lack of Participant political culture. The Himalayan Times, August 09. https://thehimalayantimes.com/opinion/democracy-in-nepallack-of- participant-political-culture/. Retrieved March 16, 2019.

Thapa, S. (2017). Decoding RPP Split. My Republica, August 27. https://myrepublica. nagariknetwork.com/news/decoding-rpp-split/.Reterived March 21, 2019. 
Thapliyal, S. (2006). Nepal at the political crossroads: options for India. New Delhi: Sage Publications. South Asian Survey 13:1, pp. 51-72.

Whelpton. J. (1993). Nepal in the Nineties (ed.) by Michael Hutt. Chapter 4-The General Elections of May 1991.New Delhi: Oxford University Press.pp.48-81.

Whelpton, J. (2003). Nepalese democracy and its discontents. Kathmandu: Himal Books. https://linguae.weebly.com/nepalese-democracy.html.Reterived March 16, 2019.

(1952). Political parties in Nepal. The Economic Weekly, July 19. https://www. epw.in/system/files/pdf/1952_4/29/political_parties_in_nepal.pdf.Retrieved March 5, 2019.

. (2019). Nepali Politics 1990-2008. https://www.globalsecurity.org/military/world/ nepal/politics-1990.htm. Retrieved date March 10, 2019.

- (1997 June). Consolidating Democracy in Nepal - Assessment Mission Report. Sweden: International IDEA. Pp.1-65.

. (1994). Nepal: parliamentary election Pratinidhi Sabha. Inter-Parliament Union. http://archive.ipu.org/parline-e/reports/arc/2386_94.htm.Retrieved March 15, 2019.

. (1991). Nepal: parliamentary election Pratinidhi Sabha. Inter-Parliament Union. http://archive.ipu.org/parline-e/reports/arc/2386_91.htm.Retreived March 15, 2019.

- (1999). 1999 Nepalese legislative election. https://en.wikipedia.org/wiki/1999 Nepalese_legislative_election.Retrieved March 15, 2019.

. Nepal: Key People and Parties. Peace Insight. https://www.peaceinsight.org/ conflicts/nepal/conflict-profile/key-people-and-parties/. Retrieved March 21, 2019.

. (2005). Main Event of the Year: Formation and Dissolution of Political Parties in Nepal.

February 20. http://www.hri.ca/partners/insec/Yb1999/Annex_2.shtml. Retrieved March 21, 2019. 


\section{Articles}

Acharya, S. (2013). Nepali Congress. Top Nepal information portal. www.topnepal.com/ article/nepali-congress. Retrieved July 27, 2019.

Basnet, P. (2018). Establishing the Nepali Congress. Lumbini Times. www.lumbinitimes. com/news/history- of- nepali- congress/. Accessed date July 25, 2019.

Gupta, A. (1994). Nepali Congress and Post-Panchayat Politics. Economic and Political Weekly, Vol.29, No.43, pp.2798-2801.

Goutm, S. (2019). Nepali Congress Party: leftist or rightist? Lokaantar. english.lokaantar.com/ articles/nepali-congress-party-leftist-rightist/. Retrieved July 27, 2019.

Shah, B.P. (2019). Nepali Congress 4.0. My Republica, February 13. https://myrepublica. nagariknetwork.com/news/nepali-congress-4-0/. Retrieved July 27, 2019.

Wagle, T.C. (2019). Nepali Congress and Dalits. The Rising Nepal. therisingnepal.org.np/ news/9202/. Accessed date July 20, 2019.

https://en.wikipedia.org/wiki/List_of_Prime_Ministers_of_Nepal. Retrieved March 19, 2019. https://en.wikipedia.org/wiki/Rastriya_Prajatantra_Party. Retrieved March 21, 2019.

www. nepalicongress.org. "NepaliCongress.org- Nepali Congress official website Political Party of Nepal". Accessed date July 20, 2019.

http://cpnuml.org/content/prologue.html. Retrieved July 26, 2019.

https://en.wikipedia.org/wiki/Communist_Party_of_Nepal\#References. Retrieved July 26, 2019. https://ipfs.io/ipfs/QmXoypizjW3WknFiJnKLwHCnL72vedxjQkDDP1mXWo6uco/wiki/Comm unist_Party_of_Nepal (Unified Marxist-Leninist).html. Retrieved July 27, 2019.

https://thehimalayantimes.com/nepal/nepal-communist-party-ncp-moves-to-consolidateunification/. Retrieved July 27, 2019.

http://www.xinhuanet.com/english/2018-05/18/c_137187121.htm. Retrieved July 27, 2019 https://en.wikipedia.org/wiki/Nepali_Congress_(Democratic). Retrieved July 27, 2019. 
The Kathmandu Post (2015). Congress membership row rages. December 25. Retrieved July $27,2019$.

The Kathmandu Post (2018). Unified party will be named Nepal Communist Party: Leader Nepal.

February 9. http://kathmandupost.ekantipur.com/news/2018-02-09/unified-party-will-benamed-nepal-communist-party-leader-nepal.html. Retrieved March 21, 2019.

The Kathmandu Post (2016). Maoist Splinters in Bid to Merge with Mother Party. January 17. Retrieved date March 21, 2019.

The Kathmandu Post (2015). Sarita Giri, Anil Jha Unite to form NSP. March 2. kathmandupost.ekantipur.com/news/2015-03-02/sarita-giri-anil-jha-unite-to-formnsp.html. Retrieved March 21, 2019.

The New York Times. (1990). Nepal's King Gives Way to Multiparty Democracy. November 11. https://www.nytimes.com/1990/11/11/world/nepal-s-king-gives-way-tomultiparty-democracy.html. Retrieved March 14, 2019. 